\title{
Identifikasi Akuifer Berdasarkan Metode Geolistrik Susunan Schlumberger Di Kecamatan Pejagoan, Kebumen
}

\author{
Nandian Mareta ${ }^{1^{*}}$ Chusni Ansori ${ }^{1}$ \\ ${ }^{1}$ Balai Informasi dan Konservasi Kebumian, LIPI, \\ Jl. Kebumen-Karangsambung KM 19, Karangsambung, Kebumen, Jawa Tengah \\ *Penulis Penanggungjawab.E-mail: :nandianthea@gmail.com,/nand015@lipi.go.id
}

\begin{abstract}
ABSTRAK
Identifikasi airtanah menggunakan metode geolistrik susunan Schlumberger telah dilaksanakan di kecamatan Pejagoan, Kebumen. Pejagoan ini merupakan salah satu kecamatan di Kebumen yang cukup cepat perkembangan penduduknya, sehingga kebutuhan sumberdaya air juga meningkat. Setiap musim kemarau resiko kekurangan air selalu terjadi di bagian utara wilayah kecamatan. Penelitian tentang potensi airtanah dalam masih jarang dilakukan, sehingga dilakukanlah kegiatan ini. Susunan Schlumberger adalah bagian dari metode geolistrik untuk mengetahui variasi litologi bawah permukaan melalui perbedaan tahanan jenis batuan. Pengukuran geolistrik dilakukan di 13 lokasi secara sounding, panjang bentangan rata-rata 200-250 meter, dengan kedalaman yang dihasilkan antara 65 meter sampai 140 meter. Berdasarkan nilai tahanan jenis, dapat diinterpretasikan litologi yang dijumpai berupa soil, batu lempung tufaan basah, batupasir tufaan basah, batupasir tufaan kering, batu gamping dan tufa kering. Soil terdapat pada lapisan paling atas, dengan kedalaman $<10$ meter, ditandai dengan nilai tahanan jenis yang tidak sepenuhnya stabil. Batulempung tufaan basah mempunyai nilai tahanan jenis kecil (kurang dari 20 ohmmeter). Batupasir tufaan basah dengan nilai tahanan jenis 20-100 ohmmeter. Batupasir tufaan kering dan batugamping nilai tahanan jenis antara $100-1.000$ ohmmeter, sedangkan nilai tahanan jenis sangat besar ( $>2.000$ ohmmeter) diinterpretasikan sebagai tufa kering. Litologi yang dapat berfungsi sebagai akuifer setengah permeabel adalah batulempung tufaan basah dan batupasir tufaan basah. Batulempung tufaan basah berada pada kedalaman 9 - 16 m, banyak mengalami kekar sehingga dimungkinkan sebagai akuifer dangkal. Batupasir tufaan basah, pelamparannya lebih luas dapat berfungsi
\end{abstract}


sebagai akuifer setengah permeabel adalah batulempung tufaan basah dan batupasir tufaan basah. Batulempung tufaan basah berada pada kedalaman 9 - $16 \mathrm{~m}$, banyak mengalami kekar sehingga dimungkinkan sebagai akuifer dangkal. Batupasir tufaan basah, pelamparannya lebih luas dapat berfungsi sebagai akuifer pada kedalaman $52 \mathrm{~m}$ dengan ketebalan $38 \mathrm{~m}$. Sedangkan sebagai akuifer dangkal terdapat pada kedalaman 4 meter sampai 13 meter. Potensi air tanah pada akuifer dangkal sangat dipengaruhi oleh kondisi musim.

Keywords: Geolistrik, susunan Schlumberger, vertical electrical sounding, akuifer

\begin{abstract}
Groundwater identification using the Schlumberger arrangement geoelectric method has been carried out in Pejagoan sub-district, Kebumen. Pejagoan is one of the sub-districts in Kebumen which has a fairly rapid development of its population, so that water resource needs are also increasing. Every dry season the risk of water shortages always occur in the northern part of the sub-district. Research of the potential deep groundwater is still rare, so this activity is carried out. Schlumberger arrangement is one of the geoelectric methods to determine subsurface lithology variations through different types of rock resistance. Geoelectric measurements were carried out in 13 locations by sounding, with an average stretch of 200-250 meters, with a depth of between 65 meters and 140 meters. Based on the type of resistivity value, it can be interpreted as lithology found in soil, wet tuff claystone, wet tuff sandstone, dry tuff sandstone, limestone and dry tuff. Soil is found in the uppermost layer, with a depth of $<10$ meters, which is characterized by a value of type resistance that is not completely stable. Wet tuff claystone has a small resistance value (less than 20 ohmmeter). Wet tuff sandstones with resistivity values of 20-100 ohmmeter. Dry tuff sandstones and limestone type resistivity values between 100 - 1,000 ohmmeter, while very large resistance values ( $>2,000$ ohmmeter) are interpreted as dry tuffs. The lithology that can function as a semi-permeable aquifer is wet tuff claystone and wet tuff sandstone. Wet tuff claystone is at a depth of 9-16 $\mathrm{m}$, has a lot of strength so it is possible as a shallow aquifer. Wet tuff sandstones, wider dispersion can function as aquifers at a depth of 52 $\mathrm{m}$ with a thickness of $38 \mathrm{~m}$. Whereas as a shallow aquifer there is a depth of 4 meters to 13 meters. The potential of groundwater in shallow aquifers is strongly influenced by seasonal conditions.
\end{abstract}

Keywords: Geoelectric, Schlumberger arrangement, vertical electrical sounding, aquifer 


\section{Pendahuluan}

Air adalah sumber kehidupan yang sangat esensial. Tanpa air, manusia, hewan dan tumbuhan akan sangat kesusahan untuk melangsungkan kehidupannya. Bumi kita pun hampir 2/3 -nya tertutupi oleh air. Berdasarkan pada rasanya air terbagi menjadi air tawar dan air asin. Air tawar biasanya terdapat di daratan, sementara air asin biasanya terdapat di lautan. Air sendiri berdasarkan keterdapatannya dapat dibagi menjadi air permukaan dan air bawah permukaan (airtanah). Air permukaan air yang terdapat diatas permukaan tanah seperti di sungai, danau, situ dan kolam. Air bawah permukaan (airtanah) air yang terdapat atau mengalir dibawah permukaan seperti sumur dan mataair.

Air yang kita pergunakan sehari-hari telah melalui siklus meteorik, yaitu telah mengalami proses penguapan (precipitation) dari laut, danau, maupun sungai; lalu melalui kondensasi di atmosfer dan kemudian menjadi hujan kedalam bumi [1].

Air hujan yang turun ke permukaan bumi tersebut ada yang langsung mengalir di permukaan bumi (run off) dan ada yang meresap ke bawah permukaan bumi (infiltration). Air yang langsung mengalir ke permukaan bumi tersebut ada yang mengalir ke sungai, sebagian mengalir ke danau dan akhirnya sampai kembali ke laut.
Sementara itu air yang meresap kebawah permukaan bumi melalui dua sistem, yaitu sistem air tidak jenuh (vadous zone) dan sistem air jenuh. Sistem air jenuh adalah air bawah tanah yang terdapat pada satu lapisan batuan dan berada pada suatu cekungan airtanah.

Sistem ini dipengaruhi oleh kondisi geologi, hidrogeologi dan gaya tektonik, serta struktur bumi yang membentuk cekungan air tanah tersebut. Air ini dapat tersimpan dan mengalir pada lapisan batuan yang kita kenal dengan akuifer (aquifer). [2].

Secara geologi kecamatan Pejagoan, Kabupaten Kebumen terdiri dari beberapa formasi batuan yaitu; Formasi Waturanda, Formasi Penosogan, Formasi Halang, Anggota Formasi Peniron dan Endapan Aluvium [3]. Formasi Waturanda tersusun oleh perselingan breksi dan batupasir merupakan formasi tertua. Formasi Penosogan tersusun oleh perselingan batupasir dan batulempung, sisipan napal dan kalkarenit, merupakan formasi yang lebih muda dari Formasi Waturanda. Formasi Halang tersusun oleh batupasir tufaan, batulempung tufaan, napal dan kalkarenit, merupakan formasi yang lebih muda dari Formasi Penosogan. Formasi Peniron, tersusun breksi polimik dengan komponen andesitik, batulempung, batupasir dengan masadasar batupasir tufaan, Formasi Peniron lebih muda dari Formasi Halang. Endapan Aluvial merupakan satuan batuan yang paling muda 
dari semua satuan batuan (formasi) tadi. Endapan Aluvial tersusun oleh sedimen yang belum terkonsolidasi, bersifat lepas-lepas, berupa lempung sampai kerikil yang merupakan hasil endapan yang terdapat di sekitar sungai maupun sepanjang pantai. Endapan aluvial ini melampar cukup luas di bagian selatan wilayah kecamatan Pejagoan. Endapan aluvial sungai (fluvial) yang paling luas dan tebal endapannya adalah sepanjang sungai Lukulo.

Berdasarkan SNI 03-2818-1992 [4] ada beberapa metode penyelidikan permukaan tanah yang dapat dilakukan, diantaranya; metode geologi, metode gravitasi, metode magnet, metode seismik dan metode geolistrik. Dari metode-metode tadi, metode geolistrik merupakan metode yang banyak sekali digunakan dan hasilnya cukup baik $[5,6,7]$.

Sebelum pengambilan airtanah dengan pemboran dalam dilakukan, terlebih dahulu dilakukan penyelidikan awal di atas permukaan tanah tentang ada tidaknya lapisan pembawa air (akuifer). Sementara itu potensi airtanah (akuifer) yang ada di Pejagoan tidak diketahui secara pasti karena belum pernah dilakukan penelitian sebelumnya.

\section{Bahan Dan Metoda}

Airtanah mempunyai tahanan jenis yang lebih rendah dibandingkan daripada batuan mineral. Prinsip kerja pendugaan geolistrik adalah mengukur tahanan jenis (resistivity) dengan mengalirkan arus listrik kedalam batuan atau tanah melalui elektroda arus (current elektrode), kemudian arus diterima oleh elektroda potensial. Beda potensial antara dua elektroda tersebut diukur dengan voltmeter dan dari harga pengukuran tersebut dapat dihitung tahan jenis semua batuan dengan menggunakan rumus sebagai berikut $[4,8,9]$.

$$
\rho=2 \cdot \pi \cdot a_{1} \frac{v}{I}
$$

Dimana $\rho$ adalah tahanan jenis, $2 \pi$ konstanta, $\mathrm{V}$ adalah beda potensial, I adalah kuat arus dan $\alpha$ adalah jarak elektroda.

Metode resistivitas dengan susunan Schlumberger dilakukan dengan cara mengkondisikan spasi antar elektroda potensial adalah tetap sedangkan spasi antar elektroda arus berubah secara bertahap [5]. Pengukuran pada arah vertikal atau vertical electrical sounding (VES) merupakan salah satu metoda geolistrik untuk menentukan perubahan resistivitas tanah terhadap kedalaman yang bertujuan untuk mempelajari variasi resistivitas batuan di bawah permukaan bumi secara vertical [10]. Aturan ini dipakai untuk pengukuran dengan variasi harga resistivitas terhadap kedalaman. Adapun susunan elektroda untuk metode Schlumberger yaitu antara elektroda arus dan potensial adalah sebagai berikut:

$$
\Delta V=\frac{\rho L}{2 \pi}+\left(\frac{1}{r}\right)
$$




$$
\begin{aligned}
& \rho=\pi \frac{A \bar{E}^{2}-M W^{2}}{4 N W}\left(\frac{M N}{I}\right) \\
& \mathrm{k}=\pi \frac{A B^{2}-M N^{2}}{4 N W}
\end{aligned}
$$

Dimana : $\mathrm{I}=$ arus listrik $(\mathrm{mA})$ pada transmitter, $\Delta V=$ beda potensial $(\mathrm{mV})$ pada receiver, $\rho=$ resistivitas semu, $0=$ titik yang diukur secara sounding, $\mathrm{AB}=$ spasi elektroda arus $(\mathrm{m}), \mathrm{MN}=$ spasi elektrode potensial (m). Dengan syarat bahwa $\mathrm{MN}<1 / 5 \mathrm{AB}$ (menurut Schlumberger), $\mathrm{k}=$ faktor geometris.

\section{Hasil dan Pembahasan}

Pengukuran geolistrik susunan Schlumberger telah dilakukan sebanyak 13 titik yang tersebar di wilayah Kecamatan Pejagoan, Kabupaten Kebumen, Propinsi Jawa Tengah (lokasi pengukuran/plooting tersaji pada gambar 4. Pengukuran dilakukan dengan panjang bentangan total $500 \mathrm{~m}$, masing-masing 250 meter ke arah kanan dan ke arah kiri.

Dalam survei geolistrik ini menggunakan susunan elektroda aturan Schlumberger, adapun lokasi titik pengukuran geolistrik dapat dilihat pada Tabel 1.

Pada bagian utara daerah penelitian litologi tersusun oleh selang seling antara kalkarenit dengan napal Formasi Penosogan. Napal terlihat lebih dominan dibandingkan kalkarenit berlapis dengan ketebalan 20-30 cm, kedudukan $\mathrm{N} 92^{0} \mathrm{E} / 40^{0}$.

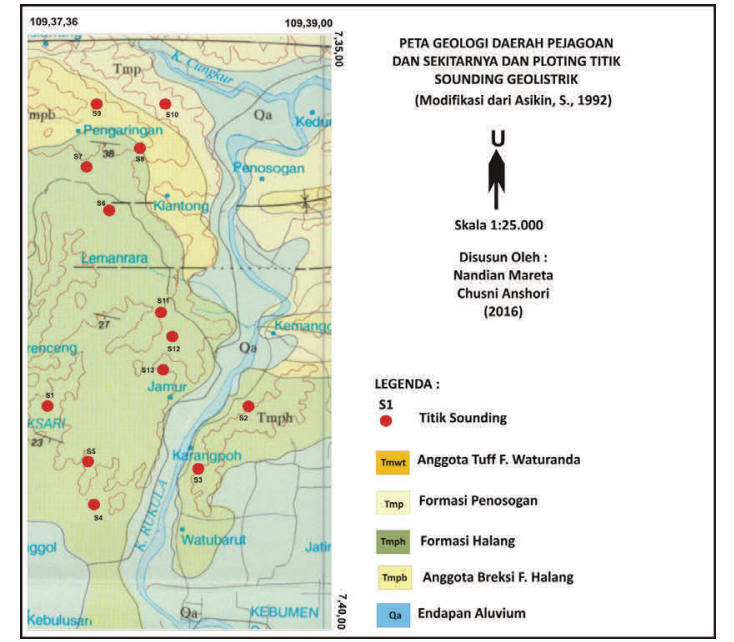

Gambar 4. Peta Plotting titik sounding

Data pengukuran lapangan selanjutnya diproses dengan menggunakan program Res2Div untuk bisa mendapatkan kolom resistivitas. Berdasarkan hasil prosesing tersebut terlihat secara vertikal adanya layer -layer (lapisan) yang berbeda. Setiap lapisan dapat diketahui jenis litologi, ketebalan dan kedalamannya. Hasil pengolahan data memperlihatkan adanya perbedaan harga tahanan jenis yang sangat kontras, yang mencerminkan adanya perbedaan litologi. Nilai kedalaman dari titik sounding berkisar antara 65 sampai 140 meter. Hal ini tergantung dari panjang bentangan dan homogenitas batuannya.

Selain dari harga resistivitasnya, untuk menduga jenis litologi juga didukung oleh data singkapan permukaan. Data permukaan menunjukkan bahwa daerah penelitian secara umum tersusun oleh litologi berupa soil, batupasir tufaan, tufa dan breksi. Batuan yang berfungsi sebagai akuifer adalah batupasir tufaan. 
Tabel 1. Lokasi pengukuran sounding geolistrik dan pengamatan geologi di Kec. Pejagoan, Kebumen

\begin{tabular}{|c|c|c|c|c|}
\hline \multirow{2}{*}{$\begin{array}{l}\text { No. } \\
\text { Lokasi }\end{array}$} & \multicolumn{3}{|c|}{ Posisi } & \multirow[t]{2}{*}{ Keterangan } \\
\hline & $\mathrm{X}$ & $\mathrm{Y}$ & Dukuh, Desa & \\
\hline 1 & $07^{0} 39^{\prime} 58.7^{\prime \prime}$ & $109^{0} 38^{\prime} 12.4 ”$ & Gunungsari, Desa Pejagoan & $\begin{array}{l}\text { Perselingan Tufa (tebal) dengan } \\
\text { bt pasir tufaan, susah air, N320 } \\
\text { E/30 }\end{array}$ \\
\hline 2 & 07039’17.9” & $109^{0} 38^{\prime} 12.5^{\prime \prime}$ & Perbatasan Kr.Poh-Pakuran & $\begin{array}{l}\text { Perselingan antara tufa (tebal) } \\
\text { dg bt pasir tufaan dan bt pasir, } \\
\text { susah air, N100E/ } 25\end{array}$ \\
\hline 3 & $07^{0} 37^{\prime} 48.6 ”$ & $109^{0} 38^{\prime} 41.3 ”$ & Lengkong, Jemur & $\begin{array}{l}\text { Perselingan antara tufa (tebal) } \\
\text { dg bt pasir tufaan, susah air, } \\
\text { N100 E/30 }\end{array}$ \\
\hline 4 & $07^{0} 36 ’ 38.6 ”$ & $109^{0} 39^{\prime} 01.2 ”$ & Watu Rupit, Kebagoran & $\begin{array}{l}\text { Sisipan breksi andesit di sekitar } \\
\text { bt pasir tufaan, N260E/22 }\end{array}$ \\
\hline 5 & $07^{0} 35^{\prime} 57.2^{\prime \prime}$ & $109^{0} 38^{\prime} 59.4 "$ & Kalimacan, Kebagoran & $\begin{array}{l}\text { selang seling antara bt lempung } \\
\text { tufaan dan lanau, fracture, } \\
\text { N110E/27 }\end{array}$ \\
\hline 6 & $07^{0} 35^{\prime} 25.7^{\prime \prime}$ & $109^{0} 38^{\prime} 54.4 ”$ & Tegong, Peniron & $\begin{array}{l}\text { Selang seling antara kalkarenit } \\
\text { dg napal, susah air, N } 92 \text { E/40 }\end{array}$ \\
\hline 7 & $07^{0} 35^{\prime} 02.6^{\prime \prime}$ & $109^{0} 38^{\prime} 09.9 ”$ & SD Watu lawang & $\begin{array}{l}\text { Bt lempung tufaan dan tufa } \\
\text { tebal, susah air, N83 E/90 }\end{array}$ \\
\hline 8 & $07^{0} 35^{\prime} 05.5^{\prime \prime}$ & $109^{0} 37^{\prime} 38.6^{\prime \prime}$ & Era, Watu lawang & $\begin{array}{l}\text { Perselingan bt lempung, bt. } \\
\text { pasir tufaan, susah air, N30E/40 }\end{array}$ \\
\hline 9 & $07^{0} 35^{\prime} 20.5^{\prime \prime}$ & $109^{0} 38^{\prime} 01.2 ”$ & Watu lawang & $\begin{array}{l}\text { Selang seling antara bt pasir } \\
\text { tufaan-tufa, sisipan breksi } \\
\text { vulkanik, ada mata air, N93 } \\
\text { E/10 }\end{array}$ \\
\hline 10 & $07^{0} 35^{\prime} 53.8^{\prime \prime}$ & $109^{0} 38^{\prime} 15.8^{\prime \prime}$ & Balai Desa Pengaringan & $\begin{array}{l}\text { Perselingan bt pasir tufaan, bt } \\
\text { lempung tufaan, sisipan breksi, } \\
\text { susah air }\end{array}$ \\
\hline 11 & $07^{0} 36^{\prime} 34^{\prime \prime}$ & $109^{0} 38^{\prime} 38.6^{\prime \prime}$ & Prigi & $\begin{array}{l}\text { Perselingan bt pasir tufaan, } \\
\text { lempung tufaan, susah air, N } \\
189 \mathrm{E} / 80\end{array}$ \\
\hline 12 & $07^{0} 37^{\prime} 14,5^{\prime \prime}$ & $109^{0} 38^{\prime} 39.2 ”$ & Balai Desa Prigi & $\begin{array}{l}\text { Perselingan bt lempung tufaan } \\
\text { dg bt pasir tufaan, susah air, N } \\
65 \mathrm{E} / 12\end{array}$ \\
\hline 13 & $07^{0} 37^{\prime} 28.2^{\prime \prime}$ & $109^{0} 38^{\prime} 51.1^{\prime \prime}$ & Kalidlingo, Jemur & $\begin{array}{l}\text { Perselingan bt pasir tufaan dg } \\
\text { tufa, susah air, N133 E/10 }\end{array}$ \\
\hline
\end{tabular}

Soil umumnya dijumpai pada lapisan paling atas, dengan kedalaman $<10$ meter, yang ditandai dengan nilai tahanan jenis yang tidak sepenuhnya stabil. Nilai tahanan jenis yang sangat kecil (kurang dari 20 ohmmeter) dimungkinkan sebagai batuan yang didalamnya terisi air. Batuan yang mengandung air akan cenderung menghantarkan arus yang baik (nilai arusnya besar), sehingga nilai tahanan jenisnya akan kecil. Di daerah penelitian yang memungkinkan mempunyai nilai tahanan jenis sangat kecil ini adalah batulempung atau batulempung tufaan yang bersifat basah. Seperti pada sounding 3, 4, 7, 9 dan 12. Batulempung ini dapat terisi air dimungkinkan karena pada batuan tersebut banyak rekahan. 
Selain pada batulempung tufaan, batuan yang dimungkinkan bersifat basah adalah batupasir tufaan basah dengan nilai tahanan jenis 20-100 ohmmeter. Seperti pada sounding 3, 4, 7, 9, 11, 12 dan 13. Kedua batuan tersebut (batulempung tufaan basah dan batupasir tufaan basah) dimungkinkan sebagai akuifer yang ada di daerah penelitian. ohmmeter, mengindikasikan batuan yang sudah bersifat kering yaitu batupasir tufaan kering serta batugamping (kalkarenit). Seperti pada sounding 2, 3, 6, 7, 8, 9, 11, 12 dan 13 . Sedangkan nilai tahanan jenis sangat besar (>2.000 ohm meter) diinterpretasikan sebagai tufa kering, seperti di sounding 1, 5, 10 dan 13. Hasil interpretasi pembacaan geolistrik di titik 1 sampai 13 dapat terbaca pada tabel 2.

Tabel 2. Hasil Pembacaan Geolistrik di Kec. Pejagoan, Kebumen

\begin{tabular}{|c|c|c|c|c|}
\hline $\begin{array}{c}\text { No. } \\
\text { Lokasi }\end{array}$ & Tahanan Jenis ( $\rho$ ) Ohm.m & $\begin{array}{c}\text { Interpretasi } \\
\text { Litologi }\end{array}$ & $\begin{array}{c}\text { Kedalaman } \\
\text { (meter) }\end{array}$ & Koordinat \\
\hline \multirow[t]{2}{*}{1} & $3,75-110,84$ & Soil & $0-7,6$ & $109^{\circ} 38^{\prime} 12.4 ” \mathrm{BT}$ \\
\hline & $5.495,31-6.106,26$ & Tufa kering & $7,6-140$ & 7³9'58.7'"LS \\
\hline \multirow[t]{2}{*}{2} & $1,21-6,03$ & Soil & $0-6,83$ & $109^{\circ} 38^{\prime} 12.5 ” \mathrm{BT}$ \\
\hline & $147,88-519,10$ & Batupasir tufaan kering & $6,83-120$ & 7³9’17.9’'LS \\
\hline \multirow[t]{4}{*}{3} & $0,79-13,01$ & Soil & $0-9,36$ & $109^{\circ} 38^{\prime} 41.3 ” \mathrm{BT}$ \\
\hline & $3,47-13,13$ & Batulempung tufaan basah & $9,36-16,48$ & 7³7'48.6’'LS \\
\hline & $39,99-91,08$ & Batupasir tufaan basah & $16,48-31,32$ & \\
\hline & $236,35-1.439,08$ & Batupasir tufaan kering & $31,32-70$ & \\
\hline \multirow[t]{4}{*}{4} & $0,35-4,86$ & Soil & $0-11,16$ & $109^{\circ} 39^{\prime} 01.2 ” \mathrm{BT}$ \\
\hline & 3,06 & Batulempung tufaan basah & $11,16-17,56$ & 7³6’38.6”LS \\
\hline & 29,75 & Batupasir tufaan basah & $17,56-25,46$ & \\
\hline & $140,27-609,27$ & Batupasir tufaan kering & $25,46-94$ & \\
\hline \multirow[t]{2}{*}{5} & $0,07-3,76$ & Soil & $0-4,07$ & $109^{\circ} 38^{\prime} 59.41$ ”BT \\
\hline & $2.805,47-12.001,03$ & Tufa kering & $4,07-65$ & $7^{\circ} 35^{\prime} 57.2^{\prime \prime} \mathrm{LS}$ \\
\hline \multirow[t]{3}{*}{6} & $0,35-11,04$ & Soil & $0-10,53$ & $109^{\circ} 37^{\prime} 38.6 ” \mathrm{BT}$ \\
\hline & 191,45 & Batupasir karbonatan kering & $10,53-24,12$ & 7'35'25.7'LS \\
\hline & $659,63-1.115,63$ & Kalkarenit kering & $24,12-105$ & \\
\hline \multirow[t]{4}{*}{7} & $0,17-28,94$ & Soil & $0-9,28$ & $109^{\circ} 38^{\prime} 09.9 ” \mathrm{BT}$ \\
\hline & 211,70 & Batupasir tufaan kering & $9,28-52,89$ & 7³5'02.6’LS \\
\hline & 39,96 & Batupasir tufaan basah & $52,89-90,40$ & \\
\hline & 8,80 & Batulempung tufaan basah & $90,40-132$ & \\
\hline \multirow[t]{2}{*}{8} & $0,04-25,69$ & Soil & $0-2$ & $109^{\circ} 37^{\prime} 38.6 ” \mathrm{BT}$ \\
\hline & $739,42-1.077,02$ & Batupasir tufaan kering & $2-60$ & $7^{\circ} 35^{\prime} 05.5^{\prime \prime} \mathrm{LS}$ \\
\hline \multirow[t]{4}{*}{9} & $2,89-6,18$ & Soil & $0-8,56$ & $109^{\circ} 37^{\prime} 17.60$ ”BT \\
\hline & $2,87-5,21$ & Batulempung tufaan basah & $8,56-21,63$ & $7^{\circ} 35^{\prime} 19.56^{\prime \prime} \mathrm{LS}$ \\
\hline & 27,58 & Batupasir tufaan basah & $21,63-37,80$ & \\
\hline & $131,06-220,70$ & Batupasir tufaan kering & $37,80-125$ & \\
\hline \multirow[t]{2}{*}{10} & $0,01-25,27$ & Soil & $0-4,35$ & $109^{\circ} 38^{\prime} 15.8 ’ \mathrm{BT}$ \\
\hline & $16.076,11-43.912,14$ & Tufa kering & $4,35-110$ & $7^{\circ} 35^{\prime} 53.8^{\prime \prime} \mathrm{LS}$ \\
\hline \multirow[t]{3}{*}{11} & $2,25-6,25$ & Soil & $0-3,96$ & $109^{\circ} 38^{\prime} 39.2 ” \mathrm{BT}$ \\
\hline & $29,39-35,03$ & Batupasir tufaan basah & $3,96-28,91$ & 7³6’34.13”'LS \\
\hline & $197,25-1.284,29$ & Batupasir tufaan kering & $28,91-82$ & \\
\hline \multirow[t]{5}{*}{12} & $0,01-6,72$ & Soil & $0-3,27$ & $109^{\circ} 38^{\prime} 39.2 ” \mathrm{BT}$ \\
\hline & 71,95 & Batupasir tufaan basah & $3,27-16,58$ & $7^{\circ} 37^{\prime} 28.2^{\prime \prime} \mathrm{LS}$ \\
\hline & 11,35 & Batulempung basah & $16,58-30,40$ & \\
\hline & 50,79 & Batupasir tufaan basah & $30,40-47,61$ & \\
\hline & $1.068,41$ & Batupasir tufaan kering & $47,61-70$ & \\
\hline \multirow[t]{5}{*}{13} & $0,13-13,49$ & Soil & $0-2$ & $109^{\circ} 38^{\prime} 51.1 ” \mathrm{BT}$ \\
\hline & 246,923 & Batupasir tufaan kering & $2-13,74$ & 7³7’28.2’'LS \\
\hline & 28,79 & Batupasir tufana basah & $13,74-41,64$ & \\
\hline & 635,61 & Batupasir tufaan kering & $41,64-82,82$ & \\
\hline & $4.205,83$ & Tuf kering & $82,82-120$ & \\
\hline
\end{tabular}


Berdasarkan hasil pengolahan data tahanan jenis maka dapat diinterpretasikan jenis litologi dan kedalamannya. Batuan yang diduga dapat berfungsi sebagai akuifer ialah batupasir tufaan basah serta batulempung tufaan basah yang mengalami banyak retakan. Kolom litologi titik sounding dapat dilihat gambar 5 sampai 8 .
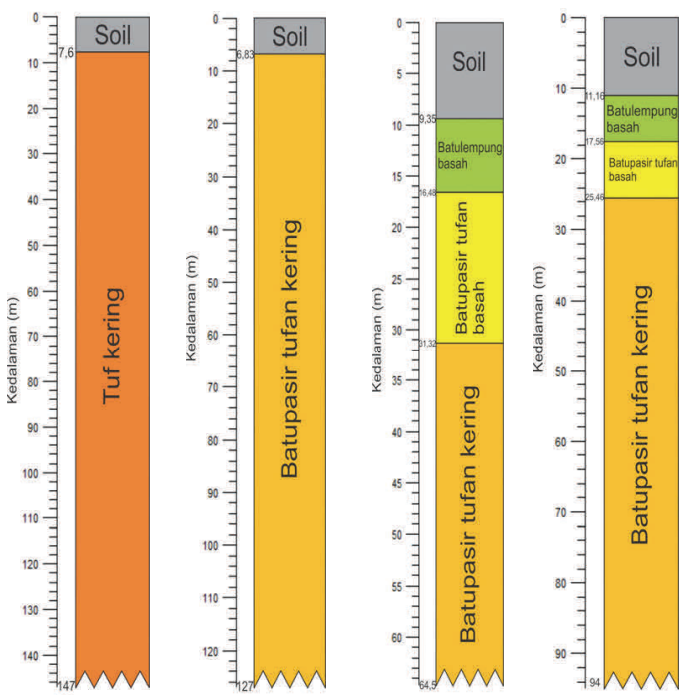

Gambar 5. Kolom litologi Sounding 1-4
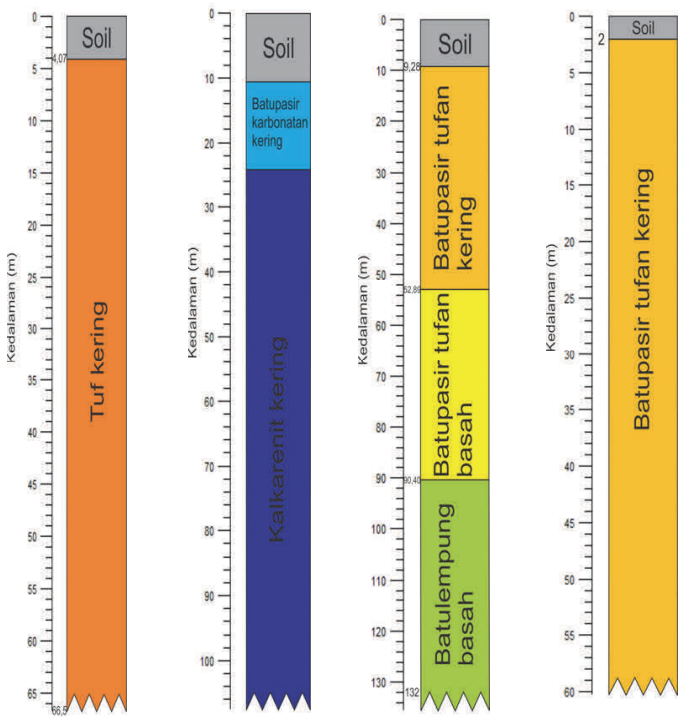

Gambar 6. Kolom litologi Sounding 5-8
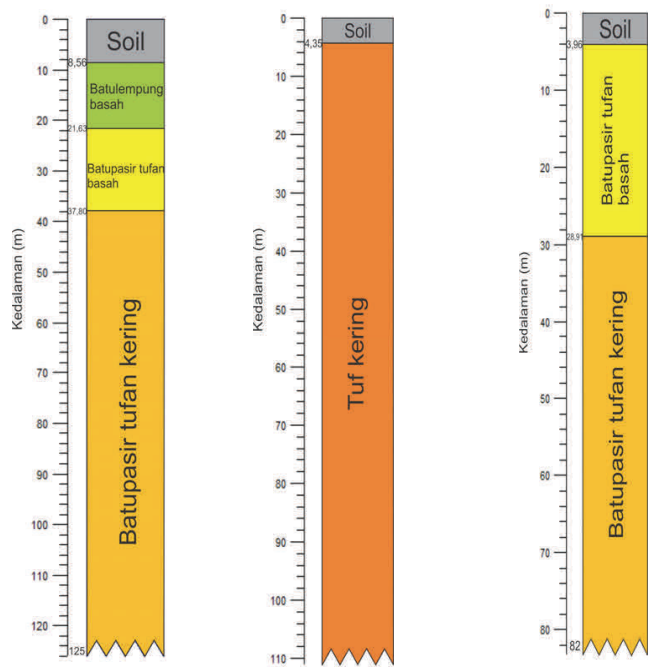

Gambar 7. Kolom litologi Sounding 9-11
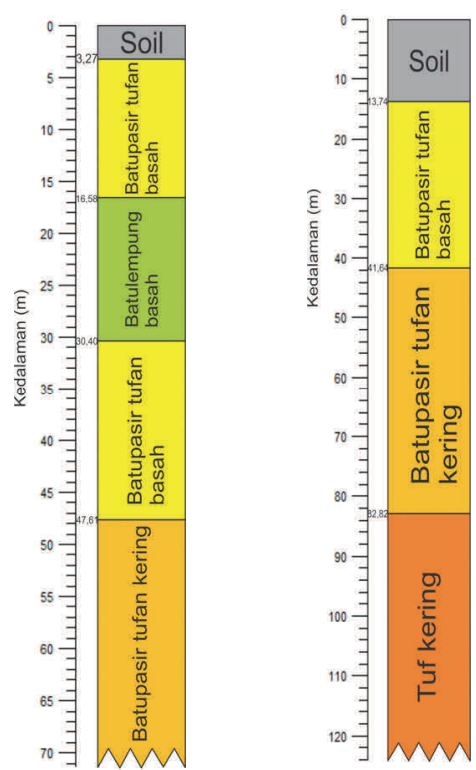

Gambar 8. Kolom litologi Sounding 12-13

Berdasarkan pada hasil pembacaan data litologi di atas, maka dapat dibuat peta sebaran dari lapisan batuan dalam bentuk korelasi yang menggambarkan sebaran batuan termasuk didalamnya sebaran akuifer. Untuk lebih menggambarkan sebaran akuifer, maka dibuat beberapa korelasi antar titik sounding yaitu : 
1. Korelasi I $: 8,7,9,6,5,10,4$ $11,12,13,3,2,1$

2. Korelasi II $: 8,9,10,11,12,13$, $3,2,1$

3. Korelasi III $: 7,6,5,4$

4. Korelasi IV : 6,5 dan 10

Selengkapnya hasil korelasi beberapa titik sounding yang dilakukan tersaji pada gambar 10. Hasil korelasi dari seluruh data sounding (korelasi I) menunjukkan bahwa dari utara ke selatan, batuan penyusun berupa batupasir tufaan, tufa, batulempung tufaan dan batuan karbonat. Batupasir tufaan kering dan tufa cukup mendominasi. Batupasir tufaan ada yang bersifat kering dan basah. Batuan yang bisa menjadi akuifer semi permeabel (aquitard) adalah batulempung tufaan basah dan batupasir tufaan basah. Batulempung tufaan basah dijumpai secara setempat dengan pelamparan yang tidak terlalu luas dengan ketebalan tipis. Batulempung tufaan basah dijumpai pada sounding 3 dan 4 ketebalannya sekitar 6 meter, sounding 9 ketebalannya 12 meter dan sounding 12 ketebalannya 13 meter. Akuifer tersebut berada pada kedalaman antara 9 sampai 16 meter. Dengan melihat kondisi tersebut, maka dimungkinkan merupakan akuifer semi permeabel dangkal yang keberadaan air sangat dipengaruhi oleh kondisi musim. Sedangkan pada sounding 7 , batulempung tufaan basah dijumpai pada kedalaman 90 meter, dengan penyebaran yang juga tidak terlalu luas. Akan tetapi akuifer pada kedalaman ini dimungkinkan merupakan akuifer dalam.

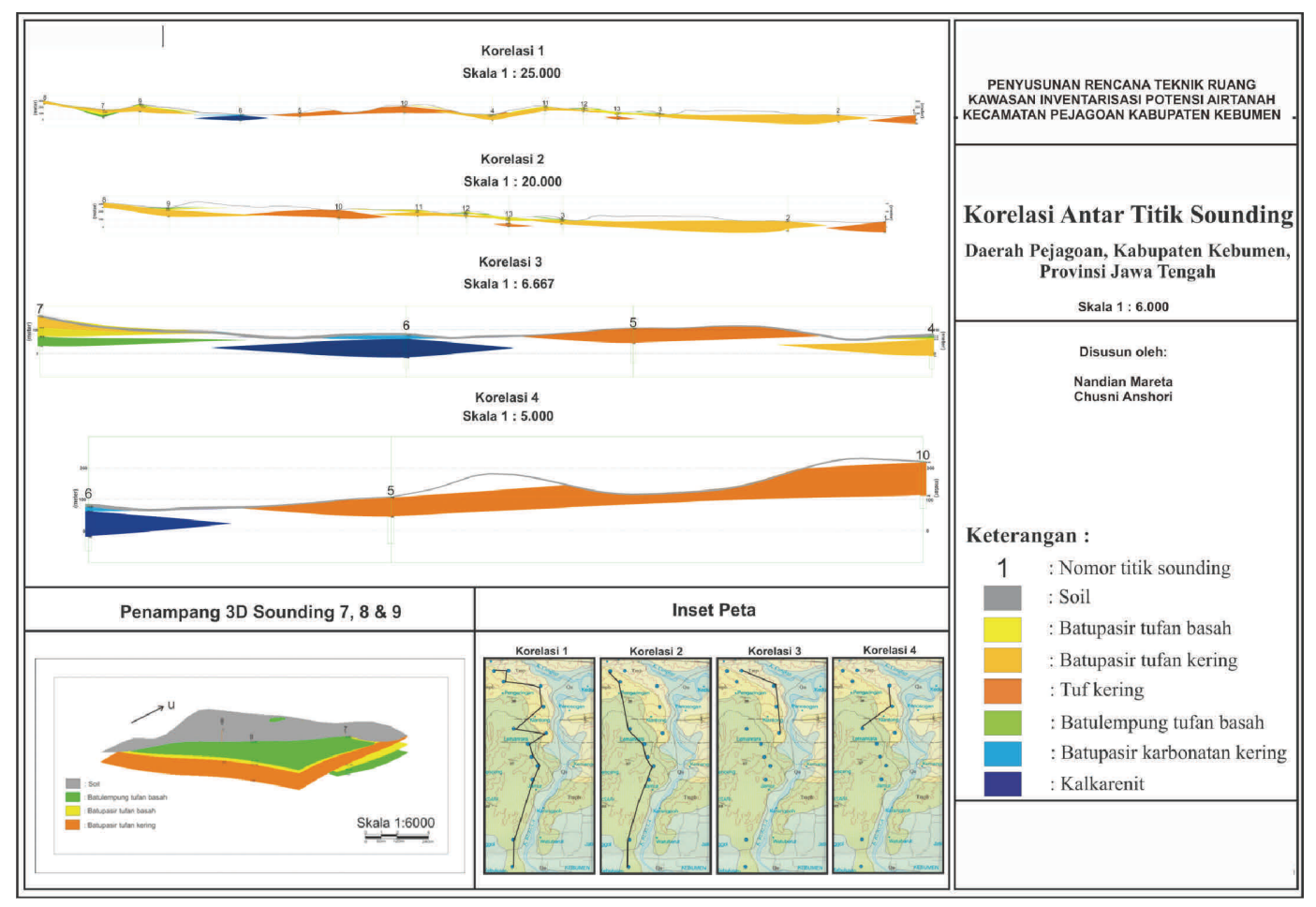

Gambar 10. Peta korelasi antar lintasan sonding 
Batuan yang juga berfungsi sebagai akuifer adalah batupasir tufaan basah. Penyebaran dari batupasir tufaan basah ini juga secara setempat-setempat, akan tetapi pelamparannya lebih luas dibandingkan batulempung tufaan basah. Pada sounding 7 batuan ini dijumpai pada kedalaman 52 meter dengan ketebalan 38 meter. Pada sounding 9 kedalaman batupasir tufaan basah ada di kedalaman 8 meter (dangkal) dengan ketebalan 12 meter. Pada sounding 3, 4, 11, 12, dan 13 secara umum batupasir tufaan basah menempati posisi dangkal yaitu pada kedalaman antara 4 meter sampai 13 meter. Sehingga dimungkinkan akuifer di sepanjang lintasan ini merupakan akuifer dangkal.

Akuifer yang di bagian selatan (3, 4, 11, 12 dan 13) cenderung berada di bagian atas (dangkal), sedangkan akuifer di bagian utara (7 dan 9) sebagian ada yang dangkal dan sebagian ada yang dalam. Hasil korelasi barat timur (korelasi IV) yang diwakili oleh sounding 5, 6 dan 10, secara umum batuan didominasi oleh tufa kering dan sisipan batuan karbonat. Sepanjang lintasan ini tidak terindikasi adanya lapisan batuan yang mengandung air.

\section{Simpulan}

Berdasarkan nilai tahanan jenis, dapat diinterpretasikan litologi yang dijumpai berupa soil, batulempung tufaan basah, batupasir tufaan basah, batupasir tufaan kering, batu gamping dan tufa kering. Soil terdapat pada lapisan paling atas, dengan kedalaman $<10$ meter, ditandai dengan nilai tahanan jenis yang tidak sepenuhnya stabil. Batulempung tufan basah mempunyai nilai tahanan jenis kecil (kurang dari 20 ohmmeter). Batupasir tufaan basah dengan nilai tahanan jenis 20 -100 ohmmeter. Batupasir tufaan kering dan batugamping nilai tahanan jenis antara $100-1.000$ ohmmeter, sedangkan nilai tahanan jenis sangat besar $(>2.000$ ohmmeter) diinterpretasikan sebagai tufa kering. Litologi yang dapat berfungsi sebagai akuifer setengah permeabel adalah batulempung tufaan basah dan batupasir tufaan basah. Batulempung tufaan basah kemunculan air bisa disebabkan karena banyaknya retakan, merupakan akuifer dangkal yang keberadaan air sangat dipengaruhi oleh kondisi musim, dijumpai secara setempat dengan pelamparan yang tidak terlalu luas dan ketebalan tipis. Pada sounding 3 dan 4 ketebalannya sekitar 6 meter, sounding 9 ketebalannya 12 meter dan sounding 12 ketebalannya 13 meter. Sedangkan pada sounding 7 , batulempung tufaan basah dijumpai pada kedalaman 90 meter, dengan penyebaran yang juga tidak terlalu luas. Akan tetapi akuifer pada kedalaman ini dimungkinkan merupakan akuifer dalam. Batupasir tufaan basah, pelamparannya lebih luas dibandingkan batulempung tufaan basah. Pada sounding 7 batuan ini dijumpai pada kedalaman 52 
meter dengan ketebalan 38 meter. Pada sounding 9 kedalaman 8 meter (dangkal) dengan ketebalan 12 meter. Pada sounding 4, 11, 12, 13 dan 3 secara umum batupasir tufaan basah menempati posisi dangkal yaitu pada kedalaman antara 4 meter sampai 13 meter.

Dengan melihat pola keberadaan akuifer di daerah penelitian, maka jika dibuat sumur bor lokasi yang disarankan adalah lokasi sounding 7 dengan kedalaman minimal $60 \mathrm{~m}$, sehingga akan diperoleh akuifer yang bersifat dalam. Lokasi lain yang kemungkinan prospektif ditemukan akuifer bersifat dangkal untuk dilakukan pemboran secara berurutan adalah lokasi sounding 3, 4, 9, 11, 12,13, dan 14.

\section{Ucapan Terima Kasih}

Kami mengucapkan terimakasih kepada Pemda Kebumen, Jawa Tengah yang telah memberikan kesempatan kepada penulis untuk melakukan kegiatan penelitian ini.

\section{Referensi}

1. Sapari. D.H.M., dkk., 2006; Sebaran Akuifer dan Pola Aliran Air Tanah di Kecamatan Batuceper dan Kecamatan Benda, Kota Tangerang, Provinsi Banten; Jurnal Geologi Indonesia, Vol. I No.3, hal. 115-128

2. Halik, G., Widodo, S.,J., 2008; Pendugaan Potensi Air Tanah dengan
Metode Geolistrik Konfigurasi Schlumberger di Kampus Tegal Broto Universitas Jember; Media Teknik Sipil hal. 109-114

3. Asikin, S., Harsolumakso, A.H., Busono, H., Gafoer, S., (1992); Peta Geologi Lembar Banyumas, P3G Bandung

4. Anonim, 1992; Standar Metoda Eksplorasi Air Tanah dengan Geolistrik Susunan Schlumberger; SNI 03-2818-1992, Departemen Pekerjaan Umum, Jakarta

5. Bisri, Mohammad., 1991; Aliran Air Tanah Malang; Fakultas Teknik Universitas Brawijaya

6. Azhar, Handayani, G., 2004; Penerapan Metoda Geolistrik Konfigurasi Schlumberger untuk Penentuan Tahanan Jenis Batubara; Jurnal Natur Indonesia Vol 6. No. 2, hal. 122-126, ISSN 1410-9379

7. N D Ardi et al 2018 J. Phys.: Con. Ser. 1013012185

8. Todd, D.K., 1980. Groundwater Hydrology. John Wiley and Sons. New York

9. Utaya, Sugeng., 1990: Pengantar Hidrogeologi: Konsep Dasar Hidrologi; Universitas Negeri Malang

10. Telford, W M, et al.,1990; Applied Geophysics Second Edition; New York; Cambridge University Press 